\title{
LIMBAH FLY ASH PABRIK MINYAK NABATI SEBAGAI BAHAN SUBSTITUSI SEMEN DALAM PEMBUATAN BATAKO
}

\author{
FLY ASH FROM VEGETABLE OIL COMPANY WASTE TO SUBTITUTE \\ PORTLAND CEMENT IN CONCRETE BRICK FABRICATION
}

\author{
Doly Prima Silaban dan A. Luther Ola \\ Balai Riset dan Standardisasi Industri Manado \\ Jalan Diponegoro No.21-23 Manado 95112 \\ Telp. (0431) 852395, Fax. (0431) 852396 \\ Pos-el: dolyprimasilaban@gmail.com
}

\begin{abstract}
ABSTRAK
Pemanfaatan limbah fly ash dari pabrik minyak nabati sebagai bahan subtitusi semen dalam pembuatan batako telah dilakukan untuk mengatasi permasalahan lingkungan. Fly ash yang digunakan dalam penelitian ini berasal dari limbah pabrik minyak nabati di Kota Bitung. Penelitian ini menggunakan metode deskriptif dengan komposisi pasir dan fly ash sebagai variabel bebas dan semen sebagai variabel konstan. Fly ash yang digunakan memiliki nilai di bawah standar maksimum kadar logam $\mathrm{As}, \mathrm{Cd}, \mathrm{Cr}, \mathrm{Hg}$ dan $\mathrm{Pb}$ untuk uji karakteristik menurut Peraturan Pemerintah RI No 18 tahun 1999 sehingga tidak berbahaya jika digunakan sebagai bahan baku pembuatan batako. Prototipe benda uji dibuat dengan ukuran $(\mathrm{cm}) 27 \times 12 \times 8$ dengan jumlah 10 batako untuk sekali pengujian dan dilakukan dua kali pengulangan untuk mendapatkan data. Hasil kuat tekan didapatkan dari pencampuran fly ash bervariasi dari $27,77-64,22 \mathrm{~kg} / \mathrm{cm}^{2}$ dengan penyerapan air rata-rata 9,62-16,79\%. Nilai kuat tekan batako dengan campuran fly ash limbah nabati memenuhi persyaratan SNI 03-0349-1989 dengan Mutu III dan IV.
\end{abstract}

Kata Kunci: Batako, fly ash, limbah pabrik.

\begin{abstract}
Utilization of fly ash waste to subtitute Portland cement in concrete brick fabrication to resolve enviromental problem has been done. This research used fly ash from waste of vegetable oil industry at Bitung City. Descriptive method has been used to interprete data with sand and fly ash composition as free variable and portland cement composition as constant variable. At the beginning $\mathrm{As}, \mathrm{Cd}, \mathrm{Cr}, \mathrm{Hg}$ and $\mathrm{Pb}$ concentration in fly ash was analyzed and comply minimum standard on Indonesia government regulation (PP No 18 Tahun 1999) about dangerous waste, so it could be used as concrete bricks raw materials. Sample prototype dimension was molded in $(\mathrm{cm}) 27 \times 12 \times 8$ with 10 samples for one test and data was provided from two repetition. Compressive strength from fly ash mixing showed value $\left(\mathrm{kg} / \mathrm{cm}^{2}\right)$ 27.77-64.22 with water absorption value (\%) 9.62-16.79. Compressive strength value of concrete brick from fly ash mix complied with SNI 030349-1989 standard on grade III and IV.
\end{abstract}

Keywords: Concrete brick, fly ash, industrial waste.

\section{PENDAHULUAN}

Fly ash dianggap sebagai bahan limbah yang merupakan hasil samping proses pembakaran batu bara ${ }^{(1)}$. Pada saat proses penyalaan batu bara di furnace, sebagian besar bahan yang mudah menguap dan karbon pada batu bara terbakar habis. Selama pembakaran, pengotor batu bara berupa mineral (seperti lempung, kristal feldspar, kuarsa dan serpihan) melebur di dalam suspensi dan terbawa menjauh dari tungku pembakaran oleh gas buangan. Dalam proses ini, material yang melebur tersebut menjadi 
dingin dan dipadatkan ke bentuk partikel bulat seperti kaca yang disebut sebagai fly $a s h^{(2)}$. Fly ash dapat meningkatkan kemampuan, ketahanan leleh/beku, berat jenis dan daya pompa selain itu fly ash juga menurunkan efek yang tidak diinginkan seperti jumlah air, permeabilitas, dan reaksi alkali/silika pada beton ${ }^{(3)}$.

Bata beton (batako) adalah salah satu bahan bangunan berupa batu-batuan yang pengerasannya tidak dibakar dengan bahan campuran yang berupa pasir, semen Portland, air dan dapat ditambahkan bahan tambahan lainnya (additive). Mutu batako sangat dipengaruhi oleh komposisi bahan penyusunnya dan juga oleh cara pembuatannya/pencetakannya (proses manual dan pres mesin). Batako semen digunakan sebagai bahan bangunan pasangan untuk dinding dengan persyaratan sesuai SNI 3-0349-1989(4).

Pada tahun 2014 fly ash diproduksi sebanyak lebih kurang 777,1 juta ton, dan hanya dimanfaatkan kembali sebanyak $53,5 \%$ nya atau 415,5 juta ton per tahun ${ }^{(5)}$.
Penggunaan fly ash antara lain sebagai campuran media tanam ${ }^{(6)}$, sebagai adsorben ${ }^{(7)}$. Untuk limbah yang dihasilkan dari pembakaran pada tahun 2014 telah dilakukan penelitian untuk penggunaan bottom ash pada campuran batako dan penelitian ini merekomendasikan bahwa bottom ash dapat dimanfaatkan sebagai campuran batako dengan komposisi 5\%$55 \%{ }^{(8)}$, dan penggunaan bottom ash yang dihasilkan PLTU sebagai pengganti agregat halus dengan tambahan kapur pada pembuatan paving ${ }^{(9)}$. Pemanfaatan abu limbah juga dilakukan dengan menggunakan abu sawit yang berfungsi mempercepat reaksi dan masa perawatan dengan suhu ruang ${ }^{(10)}$. Untuk itu masih diperlukan alternatif pemanfaatan fly ash agar tidak menjadi masalah yang mencemari lingkungan. Penelitian ini bertujuan untuk mengetahui pengaruh pemanfaatan limbah fly ash pabrik minyak nabati sebagai bahan substitusi semen dalam pembuatan batako.

Tabel 1. Optimasi Peralatan AAS untuk metode uji Graphite Furnace

\begin{tabular}{lcccc}
\hline \multicolumn{1}{c}{ Element } & As & Cd & $\mathbf{C r}$ & $\mathbf{P b}$ \\
\hline Panjang Gelombang $(\mathrm{nm})$ & 193,7 & 228,8 & 357,9 & 283,3 \\
Slit $(\mathrm{nm})$ & 0,5 & 0,5 & 0,5 & 0,5 \\
Mode & BGC-D2 & BGC-D2 & BGC-D2 & BGC-D2 \\
Pengukuran Sinyal & Peak Area & Peak Area & Peak Area & Peak Area \\
Kalibrasi & Linier & Linier & Linier & Linier \\
Volume sampel & 20 & 20 & 20 & 20 \\
\hline
\end{tabular}

\section{METODOLOGI PENELITIAN}

Sampel yang digunakan berupa fly ash yang diperoleh dari perusahaan minyak nabati yang ada di Kota Bitung, Sulawesi Utara. Sampel yang akan digunakan diuji terlebih dahulu kadar cemaran logam $\mathrm{Pb}, \mathrm{Cd}, \mathrm{Cr}$, dan 
As dengan menggunakan metode graphite furnace peralatan AAS Shimadzu AA7000 (optimasi sesuai Tabel 1) dan Logam $\mathrm{Hg}$ menggunakan metode uap dingin AAS AA900F Perkin Elmer optimasi peralatan dilakukan sesuai dengan Tabel 2 .

Tabel 2. Optimasi Peralatan AAS untuk metode uji uap dingin $(\mathbf{H g})$

\begin{tabular}{lc}
\hline Teknik & AA - FIAS \\
Panjang Gelombang (nm) & 253,7 \\
Waktu Integrasi $(\mathbf{s})$ & 20 \\
Cell Temperature $\left({ }^{\circ} \mathbf{C}\right)$ & 100 \\
Larutan Pembawa & $3 \%(\mathrm{v} / \mathrm{v}) \mathrm{HCl}$ \\
Pengukuran Sinyal & Peak Area \\
Pereduksi & $0,2 \% \mathrm{NaBH} 4$ dalam $0,05 \% \mathrm{NaOH}$ \\
\hline
\end{tabular}

Penelitian dilakukan dengan variasi komposisi pasir dan fly ash, sedangkan penggunaan perekat berupa semen Portland dibuat konstan (tetap). Penggunaan agregat divariasikan yaitu agregat pasir kasar terdiri dari 7 bagian dan Fly ash terdiri dari 1, 2, 3 dan 4 bagian (Kode A1-A4); Agregat pasir kasar terdiri dari 10 bagian dan fly ash terdiri dari 1, 2, 3 dan 4 bagian (Kode B1-B4), semua bahan dalam perbandingan ( $\mathrm{v} / \mathrm{v})$.

Tabel 3. Rancangan benda uji/produk batako Penelitian

\begin{tabular}{cccc}
\hline \multirow{2}{*}{ Kode } & \multicolumn{3}{c}{ Bagian dalam Campuran (volume) } \\
\cline { 2 - 4 } & Semen Portland & Agregat Pasir & Fly Ash \\
\hline A0 & 1 & 7 & - \\
A1 & 1 & 7 & 1 \\
A2 & 1 & 7 & 2 \\
A3 & 1 & 7 & 3 \\
A4 & 1 & 7 & 4 \\
B0 & 1 & 10 & - \\
B1 & 1 & 10 & 1 \\
B2 & 1 & 10 & 2 \\
B3 & 1 & 10 & 3 \\
B4 & 1 & 10 & 4 \\
\hline
\end{tabular}

HASIL DAN PEMBAHASAN

\section{Cemaran Logam Fly Ash}

Sebagai pembanding (kontrol) dibuat produk batako dari bahan agregat pasir (tanpa fly ash) sejumlah 7 dan 10 bagian ditambahkan masing-masing 1 bagian semen. Prototipe benda uji dibuat produk batako menggunakan alat cetak manual dengan ukuran produk $(27 \times 12 \times 8) \mathrm{cm}$ dan dari setiap perlakuan benda uji dicetak 10 buah produk batako dengan 2 kali ulangan. 
penentuan karakteristik sifat racun (dapat dilihat di Tabel 4), sehingga fly ash tidak berbahaya jika digunakan sebagai bahan baku pembuatan batako.

Tabel 4. Kandungan cemaran logam fly ash pabrik minyak nabati

\begin{tabular}{ccc}
\hline Logam & $\begin{array}{c}\text { Konsentrasi Logam } \\
(\mathbf{p p m})\end{array}$ & $\begin{array}{c}\text { Baku Mutu TCLP Zat Pencemar dalam limbah untuk } \\
\text { penentuan karakteristik sifat racun } \\
(\mathbf{p p m})\end{array}$ \\
\hline $\mathrm{Pb}$ & 1,14 & 5,0 \\
$\mathrm{As}$ & 0,78 & 5,0 \\
$\mathrm{Cd}$ & 0,04 & 1,0 \\
$\mathrm{Cr}$ & $<0,0009$ & 5,0 \\
$\mathrm{Hg}$ & $<0,0009$ & 0,2 \\
\hline
\end{tabular}

Pengujian Fisik dan Pengamatan Batako Dari Limbah Fly Ash

Kuat Tekan

Pengujian kuat tekan batako dilakukan untuk melihat apakah batako hasil penelitian memiliki kekuatan yang memenuhi persyaratan sesuai dengan fungsional penggunaannya (sesuai Gambar 1). Hasil uji kuat tekan batako semen setelah curing/pemeliharaan selama 28 hari, menunjukkan bahwa untuk batako semen dengan komposisi bahan 1 bagian semen Portland ditambahkan agregat pasir 7 bagian dan menggunakan fly ash 1, 2, 3 dan 4 bagian mengalami penambahan kuat tekan.

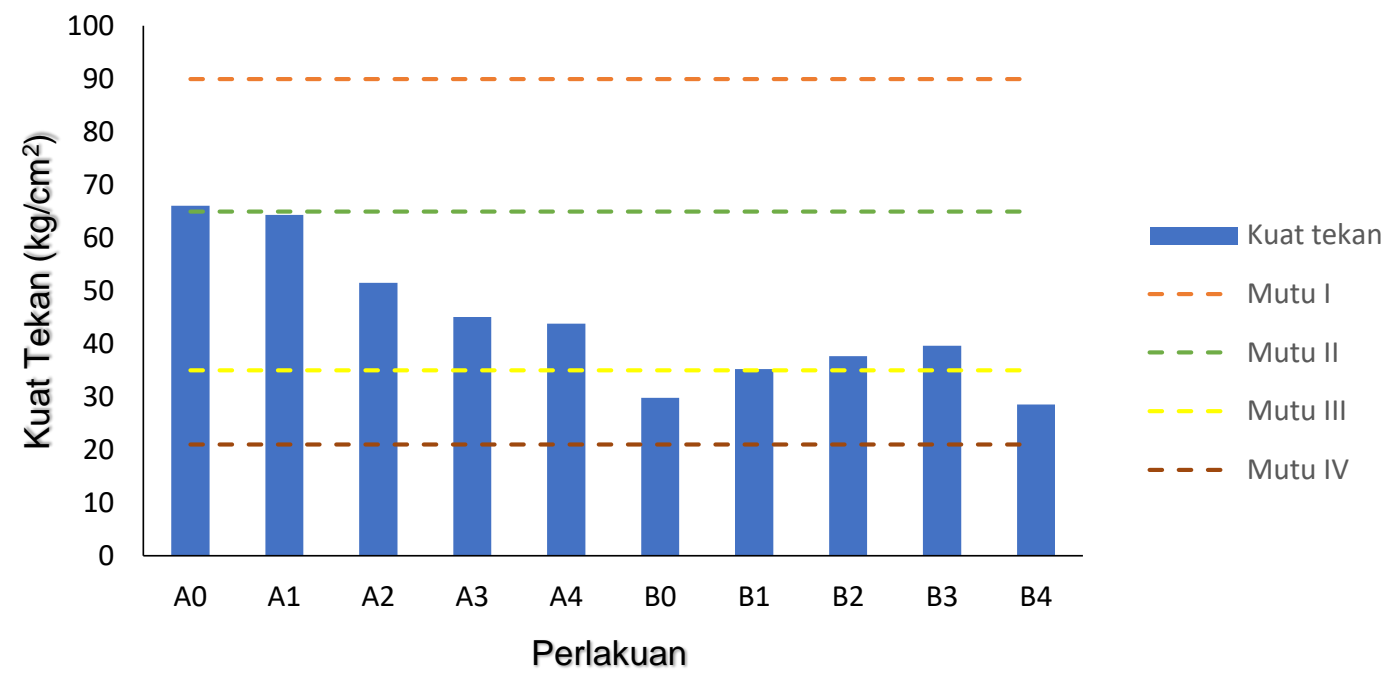

Gambar 1. Hasil Analisis Kuat Tekan Produk Batako campuran fly ash

Untuk kuat tekan tertinggi pada komposisi tersebut terdapat pada perlakuan A0 $\left(66,04 \mathrm{~kg} / \mathrm{cm}^{2}\right)$. Selanjutnya kuat tekan menurun pada perlakuan A1-A4 (64,32-43,78 $\mathrm{kg} / \mathrm{cm}^{2}$ ) Komposisi bahan pada perlakuan A1A4 dapat dikategorikan sebagai bata beton 
mutu III sesuai SNI 03-0349-1989 digunakan untuk pasangan dinding. Dibandingkan dengan kontrol $\mathrm{A} 0$, ternyata penambahan fly ash tidak banyak memberi pengaruh positif terhadap kuat tekan dalam pembuatan batako semen, akan tetapi tetap masuk dalam kelas mutu III sama dengan control A0.

Untuk perlakuan B dengan komposisi menggunakan 1 (satu) bagian semen dan Agregat pasir 10 bagian dan penambahan fly ash 1, 2, 3 dan 4 bagian memberi kuat tekan yang tertinggi pada B3 $\left(39,68 \mathrm{~kg} / \mathrm{cm}^{2}\right)$. Kemudian menurun pada B2-B1 $(37,65-35,23$ $\mathrm{kg} / \mathrm{cm}^{2}$ ) tapi masih tinggi dibandingkan kontrol B0 $\left(29,83 \mathrm{~kg} / \mathrm{cm}^{2}\right)$. Kuat tekan terendah terdapat pada perlakuan B4 $\left(28,54 \mathrm{~kg} / \mathrm{cm}^{2}\right)$, akan tetapi jika dibandingkan dengan SNI.030349-1989 maka komposit B4 juga memenuhi syarat sebagai mutu IV.
Komposisi bahan dengan perlakuan B3 dapat diklasifikasikan masuk dalam klasifikasi beton/batako semen pejal mutu III dengan kuat tekan mendekati persyaratan minimal sesuai SNI 03-0349-1989 dan komposisi bahan dengan perlakuan B2-B4 dan kontrol B0 termasuk klasifikasi mutu D sesuai SNI 030349-1989 untuk pasangan dinding. Ditinjau dari segi kuantitas dan kualitas produk batako semen yang dihasilkan, maka jelas penambahan fly ash (perlakuan B3) memberikan pengaruh positif pada kuat tekan dan kapasitas produksi. Dengan demikian komposit terbaik batako semen pejal menggunakan bahan pengisi fly ash adalah 10 bagian agregat pasir +3 bagian fly ash + 1 bagian semen Portland (B3).

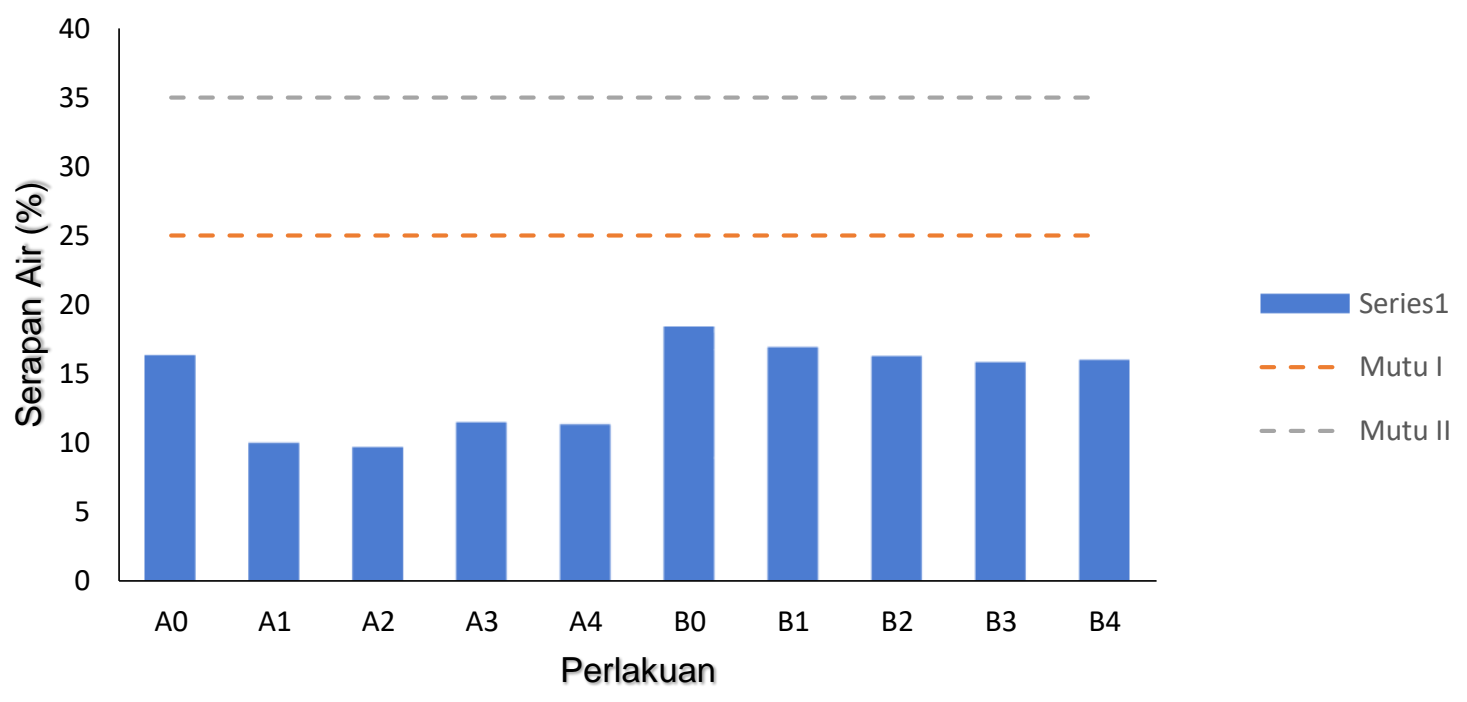

Gambar 2. Hasil uji penyerapan batako campuran fly ash terhadap air

\section{Penyerapan Air}

Dari Gambar 2 dapat dilihat hasil uji penyerapan batako campuran fly ash terhadap air dapat diketahui bahwa penyerapan air untuk perlakuan $A$ yang terendah terdapat pada $A 1(9,92 \%)$ dan yang tertinggi pada 
perlakuan A0 (16,23\%) atau dengan kata lain penyerapan air benda uji batako semen pejal hasil penelitian terdapat pada kisaran 9,92$16,23 \%$. Selanjutnya pada perlakuan B0-B4 penyerapan air lebih tinggi dan terdapat pada kisaran 15,76-18,27\%. Jika dibandingkan dengan SNI batako semen pejal yang mensyaratkan penyerapan air untuk mutu I rata-rata maksimum maksimum $25 \%$, mutu II $35 \%$ dan mutu III, IV tidak dipersyaratkan, maka untuk batako semen pejal hasil penelitian memenuhi syarat sesuai SNI 030349-1989.

\section{KESIMPULAN}

Fly Ash limbah batu bara pabrik minyak nabati dapat dimanfaatkan dalam produksi batako semen sebagai bahan subtitusi semen. Hasil penelitian dengan menggunakan 1 bagian semen+10 bagian pasir (Perlakuan B) menunjukkan bahwa penambahan fly ash untuk produksi batako semen pejal berfungsi ganda yakni sebagai pengisi yang mensubtitusi semen dan dapat meningkatkan kekuatan.

Hasil uji fisik sampel penelitian batako semen untuk komposit $A$, kuat tekan tertinggi pada perlakuan A0 $\left(66,04 \mathrm{~kg} / \mathrm{cm}^{2}\right)$ dan terendah A4 $\left(43,78 \mathrm{~kg} / \mathrm{cm}^{2}\right)$, dan pada komposit B kuat tekan tertinggi pada perlakuan B1 $\left(40,96 \mathrm{~kg} / \mathrm{cm}^{2}\right)$ dan yang terendah pada perlakuan kode B4 $(28,54$ $\mathrm{kg} / \mathrm{cm}^{2}$ ). Sedangkan uji penyerapan air untuk semua perlakuan nilai rata-rata terendah 9,92\% dan tertinggi 18,27\% memenuhi syarat sesuai standar yang ada. Berdasarkan pengamatan dan hasil uji fisik batako semen pejal dari fly ash memenuhi syarat mutu III dan IV sesuai SNI 03-0349-1989. Perlakuan A1, A2, A3, A4 dan B1 dapat digunakan untuk pasangan dinding dalam klasifikasi mutu III dan perlakuan B2, B3 dan B4 memenuhi syarat mutu IV yang dapat digunakan untuk pasangan dinding perumahan.

\section{DAFTAR PUSTAKA}

1. Malhotra VM. Role of Fly Ash in Reducing Greenhouse Gas Emissions During The Manufacturing of Portland Cement Clinker. Advances in Concrete Technologies in The Middle East. 2008 Nov:19-20.

2. Kosmatka SH, Kerkhoff B, Panarese WC. Design and Control of Concrete Mixtures, Portland Cement Association. Skokie, Illinois, USA. 2016. $16^{\text {th }}$ edition (2016) Skokie, IL United States . ISBN-10: 0893122777.

3. Gamage N, Liyanage K, Fragomeni S, Setunge S. Overview of Different Types of Fly Ash and Their Use as a Building and Construction Material. International Conference of Structural Engineering, Construction and Management, At Kandy, Sri Lanka. January 2011.

4. SNI 03-0691-1996. Bata Beton (paving block). Badan Standarisasi Nasional. Jakarta.

5. Ahmed S, Saurikhia A, Haleem A, Gangopadhyay S. Geographical Spread of Fly Ash Generation and Residual Potential for Its Utilization in India. International Journal of Innovative Research and Review. 2016;4:8-19.

6. Wardhani E, Sutisna M, Dewi AH. Evaluasi Pemanfaatan Abu Terbang (Fly Ash) Batubara sebagai Campuran Media Tanam pada Tanaman Tomat (Solanum lycopersicum). Jurnal Itenas Rekayasa. 2012 Jan 1;16(1).

7. Sutrisno B, Hidayat A, Mufrodi Z. Modifikasi Limbah Abu Layang Menjadi Adsorben untuk Mengurangi Limbah Zat Warna pada Industri Tekstil. Chemica. 2014;1(2):57-66.

8. Ristinah R, Zacoeb A, Soehardjono A, Setyowulan D. Pengaruh Penggunaan Bottom Ash Sebagai Pengganti Semen pada Campuran Batako terhadap Kuat Tekan Batako. Rekayasa Sipil. 2012;6(3):264-71.

9. Qomaruddin M, Sudarno S. Pemanfaatan Limbah Bottom Ash Pengganti Agregat Halus dengan Tambahan KapurpPada Pembuatan 
Paving. Reviews in Civil Engineering. 2017 Dec 28;1(1).

10. Syarif HA. Kuat Tekan Paving Block Geopolimer Abu Sawit (Palm Oil Fuel Ash) dengan
Perawatan Suhu Ruang. Jurnal Online Mahasiswa Fakultas Teknik Universitas

Riau.2016. Vol 3 No.1. ISSN: 2355-6970 hal 4 
